\title{
Disruption of the $A R F$ transcriptional activator DMP1 facilitates cell immortalization, Ras transformation, and tumorigenesis
}

\author{
Kazushi Inoue, ${ }^{1}$ Renren Wen, ${ }^{2}$ Jerold E. Rehg, ${ }^{3}$ Masashi Adachi, ${ }^{1,5}$ John L. Cleveland, ${ }^{2}$ \\ Martine F. Roussel, ${ }^{1}$ and Charles J. Sherr ${ }^{1,4,6}$ \\ Departments of ${ }^{1}$ Tumor Cell Biology, ${ }^{2}$ Biochemistry, ${ }^{3}$ Pathology, and ${ }^{4}$ Howard Hughes Medical Institute, \\ St. Jude Children's Research Hospital, Memphis, Tennessee 38105 USA
}

\begin{abstract}
The DMP1 transcription factor induces the $A R F$ tumor suppressor gene in mouse fibroblasts, leading to cell cycle arrest in a p53-dependent manner. We disrupted sequences encoding the DNA-binding domain of DMP1 in mouse embryonic stem cells and derived animals lacking the functional protein. DMP1-null animals are small at birth, and males develop more slowly than their wild-type littermates. Some adult animals exhibit seizures and/or obstuctive uropathy, each of unknown cause. The growth of explanted DMP1-null mouse embryo fibroblasts (MEFs) is progressively retarded as cells are passaged in culture on defined transfer protocols; but, unlike the behavior of normal cells, p19 ${ }^{\mathrm{ARF}}, \mathrm{Mdm} 2$, and $\mathrm{p} 53$ levels remain relatively low and DMP1-null MEFs do not senesce. Whereas the establishment of cell lines from MEFs is usually always accompanied by either p53 or ARF loss of function, continuously passaged DMP1-null cells readily give rise to established 3T3 and 3T9 cell lines that retain wild-type $A R F$ and functional p53 genes. Early-passage $D M P 1-n u l l$ cells, like MEFs from either $A R F$-null or $p 53$-null mice, can be morphologically transformed by oncogenic Ha-Ras (Val-12) alone. Splenic lymphocytes harvested from both DMP1-null and ARF-null mice exhibit enhanced proliferative responses in long-term cultures when stimulated to divide with antibody to CD3 and interleukin-2. Although only 1 of 40 DMP1-null animals spontaneously developed a tumor in the first year of life, neonatal treatment with dimethylbenzanthracene or ionizing radiation induced tumors of various histologic types that were not observed in similarly treated $\mathrm{DMP1}^{+/+}$animals. Karyotypic analyses of MEFs and lymphomas from DMP1-null animals revealed pseudodiploid chromosome numbers, consistent with the retention of wild-type p53. Together, these data suggest that $A R F$ function is compromised, but not eliminated, in animals lacking functional DMP1.
\end{abstract}

[Key Words: DMP1; ARF; p53; Ras transformation; tumor suppression; cell senescence]

Received April 5, 2000; revised version accepted May 24, 2000.

The retinoblastoma $(\mathrm{Rb})$ and p53 tumor suppressor proteins each regulate transcriptional programs that govern cell cycle progression (for review, see Weinberg 1995; Levine 1997). Phosphorylation of $\mathrm{Rb}$ by $\mathrm{G}_{1}$ phase cyclindependent kinases (CDKs) cancels Rb's association with histone deacetylases (Harbour et al. 1999) and releases E2F family transcription factors from $\mathrm{Rb}$ constraint, enabling the E2Fs to transactivate a series of genes that are necessary for S-phase entry (for review, see Slansky and Farnham 1996; Nevins 1998). p53, the most frequently disrupted gene in human malignancies, coordinates responses to cellular stress arising from DNA damage, hypoxia, disrupted cell adhesion, and inappropriate mi-

\footnotetext{
${ }^{5}$ Present address: Mizuno Hospital, Asahi-ku, Osaka 535-0005, Japan. ${ }^{6}$ Corresponding author.

E-MAIL sherr@stjude.org; FAX (901) 495-2381.
}

togenic signaling (for review, see Levine 1997; Prives 1998; Giaccia and Kastan 1998). Its induction, primarily through protein stabilization, triggers cell cycle arrest or apoptosis by transcriptionally activating p53-dependent target genes such as p21 ${ }^{\mathrm{Cip} 1}$, GADD45, and Bax (Kastan et al. 1992; El-Deiry et al. 1993; Miyashita and Reed 1995; for review, see Ko and Prives 1996; Levine 1997). $\mathrm{Mdm} 2$, which is also induced by $\mathrm{p} 53$, has a special role in terminating the p53 response by binding directly to p53 to prevent transcription (Momand et al. 1992; Oliner et al. 1993) and by inducing both p53 ubiquitination and proteasomal degradation (Haupt et al. 1997; Honda et al. 1997; Kubbutat et al. 1997; Midgley et al. 1997; Roth et al. 1998; Honda and Yasuda 1999l.

Like $R b$ and $p 53$, the INK4a-ARF locus also is disrupted frequently in human cancers (Ruas and Peters 1998). This locus encodes two distinct tumor suppressor 
proteins: p16 ${ }^{\mathrm{INK} 4 \mathrm{a}}$, which specifically binds to CDK4 to inhibit $\mathrm{Rb}$ phosphorylation by CDKs (Serrano et al. 1993); and p19 ARF (Quelle et al. 1995), which binds and negatively regulates $\mathrm{Mdm} 2$, thereby stabilizing and activating p53 (Kamijo et al. 1998; Pomerantz et al. 1998; Stott et al. 1998; Zhang et al. 1998; Tao and Levine 1999; Weber et al. 1999). ARF is induced by oncogenic signals resulting from overexpression of c-Myc, E2F1, adenovirus E1A, v-Abl, and activated Ras (Bates et al. 1998; De Stanchina et al. 1998; Palmero et al. 1998; Radfar et al. 1998; Zindy et al. 1998). This quenches inappropriate mitogenic signaling by forcing incipient cancer cells to undergo p53-dependent growth arrest or apoptosis, depending on the biologic setting (for review, see Sherr 1998). Although mouse p19 ARF is not detectably expressed during embryonic development, it is rapidly induced when mouse embryonic fibroblasts (MEFs) are explanted into culture and accumulates progressively as cells are passaged and become senescent (Zindy et al. 1998). In contrast, MEFs derived from INK4a/ARF-null mice (Serrano et al. 1996) or from animals lacking $A R F$ alone (Kamijo et al. 1997) become established in culture without undergoing senescence, and ARF-null cells at early passage can be transformed by oncogenic Ha-Ras, bypassing the usual requirement for so-called immortalizing oncogenes, such as c-Myc or adenovirus E1A (Land et al. 1983; Ruley 1983). Myc overexpression activates the ARF checkpoint in cultured primary MEFs, ultimately selecting for immortalized variants that have sustained either ARF loss or p53 mutations (Zindy et al. 1998). Similarly, disruption of the ARF-Mdm2-p53 pathway occurs in the majority of tumors that arise in $E \mu-$ myc transgenic mice, and c-Myc-induced lymphomagenesis is accelerated dramatically in either $A R F^{-/-}$or $A R F^{+/-}$animals (Eischen et al. 1999; Jacobs et al. 1999; Schmitt et al. 1999). Consistent with ARF's role in cellautonomous tumor surveillance (Sherr 1998), ARF-null mice are highly prone to spontaneous tumor development, and virtually all die of various forms of cancer, including lymphomas, sarcomas, carcinomas, and tumors of the central nervous system, by 15 months of age (Kamijo et al. 1997, 1999).

DMP1 is an unusual and so far poorly studied transcription factor that can induce $A R F$-dependent cell cycle arrest. The cDNA encoding this protein was originally isolated in a yeast two-hybrid interaction screen conducted with a murine T-lymphocyte cDNA library and using cyclin D2 as "bait" (Hirai and Sherr 1996). DMP1 is a 120 - to $130-\mathrm{kD}$ nuclear phosphoprotein consisting of 761 amino acids. It is composed of a central DNA-binding domain containing three Myb-like repeats flanked at the amino and carboxyl termini by acidic transactivation domains (Hirai and Sherr 1996; Inoue and Sherr 1998). The cognate human and murine DMP1 proteins are $95 \%$ identical overall and are completely identical throughout their Myb-like repeats (Bodner et al. 1999|. DMP1 binds to canonical nonameric consensus DNA sequences [CCCG(G/T)ATGT], and it competes for DNA binding with Ets-family proteins at those DNA recognition sites that contain a GGA core. DMP1 can associate physically with any of the three D-type cyclins, each of which can inhibit its ability to bind to DNA without any requirement for CDK4 or CDK6 (Inoue and Sherr 1998; Inoue et al. 1998). Enforced DMP1 expression blocks MEF cell proliferation but can be antagonized specifically by concomitant overexpression of Dtype cyclins (Inoue et al. 1999). DMP1 and E2F1 each bind to sites in the murine $A R F$ promoter to additively induce gene expression; but unlike E2F-1, DMP1 induces p53-dependent cell cycle arrest and not apoptosis (Inoue et al. 1999). Importantly, ARF-null MEFs are refractory to DMP1-induced growth arrest, implying that DMP1 might have a supporting role in tumor suppression (Inoue et al. 1999). Given these findings, we disrupted the $D M P 1$ gene in mice and now report that DMP1 loss of function mimics key aspects of the ARF-null phenotype.

\section{Results}

\section{Targeted disruption of DMP1 in mice}

We screened a 129SV mouse genomic library with a cDNA probe encoding the central Myb-repeat domain of DMP1 (amino acids 253-380) and isolated clones containing six internal exons of the DMP1 gene (Fig. 1). A targeting cassette containing a neomycin-resistance marker was designed to disrupt the $D M P 1$ gene by removing exons encoding amino acids essential for DNA binding (Inoue and Sherr 1998). Embryonic stem (ES) cell clones, screened for homologous recombination by Southern blotting analysis, were microinjected into C57BL/ 6 blastocysts that were used to generate chimeric animals, and chimeric mice derived from two independently targeted ES cell clones transmitted the disrupted allele through the germ line. Heterozygotes were mated to produce control DMP1 wild-type $(+/+)$, heterozygote $(+/-)$, and nullizygote $(-/-)$ founder strains, as verified by Southern blotting analysis of tail DNA (Fig. 1B). Results obtained with the two independently derived DMP1-null strains were indistinguishable. Whereas multiple phosphorylated forms of DMP1 (Hirai and Sherr 1996) are most highly expressed in testis, thymus, and brain of wild-type animals (Fig. 1C), the same phosphoproteins could not be detected in organs from DMP1-null mice using antibodies to a carboxy-terminal epitope or to the Myb-repeat domain (data not shown). Because the targeting strategy left the $5^{\prime}$ end of the DMP1 gene intact, the amino-terminal portion of the protein may be synthesized in DMP1-null animals. This could not be documented, as we lack antibodies that detect epitopes in this region. However, no dominant-negative effects on transcription or cell cycle progression have been ascribed to $D M P 1$ deletion and point mutants defective in DNA binding (Inoue and Sherr 1998).

Overall, the frequencies of DMP1 wild-type, heterozygous, and nullizygous animals at 3 weeks postpartum were $29.2 \%, 52.6 \%$, and $18.2 \%$, respectively (total animals 209), whereas $27 \%$ of embryonic day (E) 13.5 embryos generated from multiple breedings scored as $D M P 1$-null. This indicated that some DMP1-null mice 

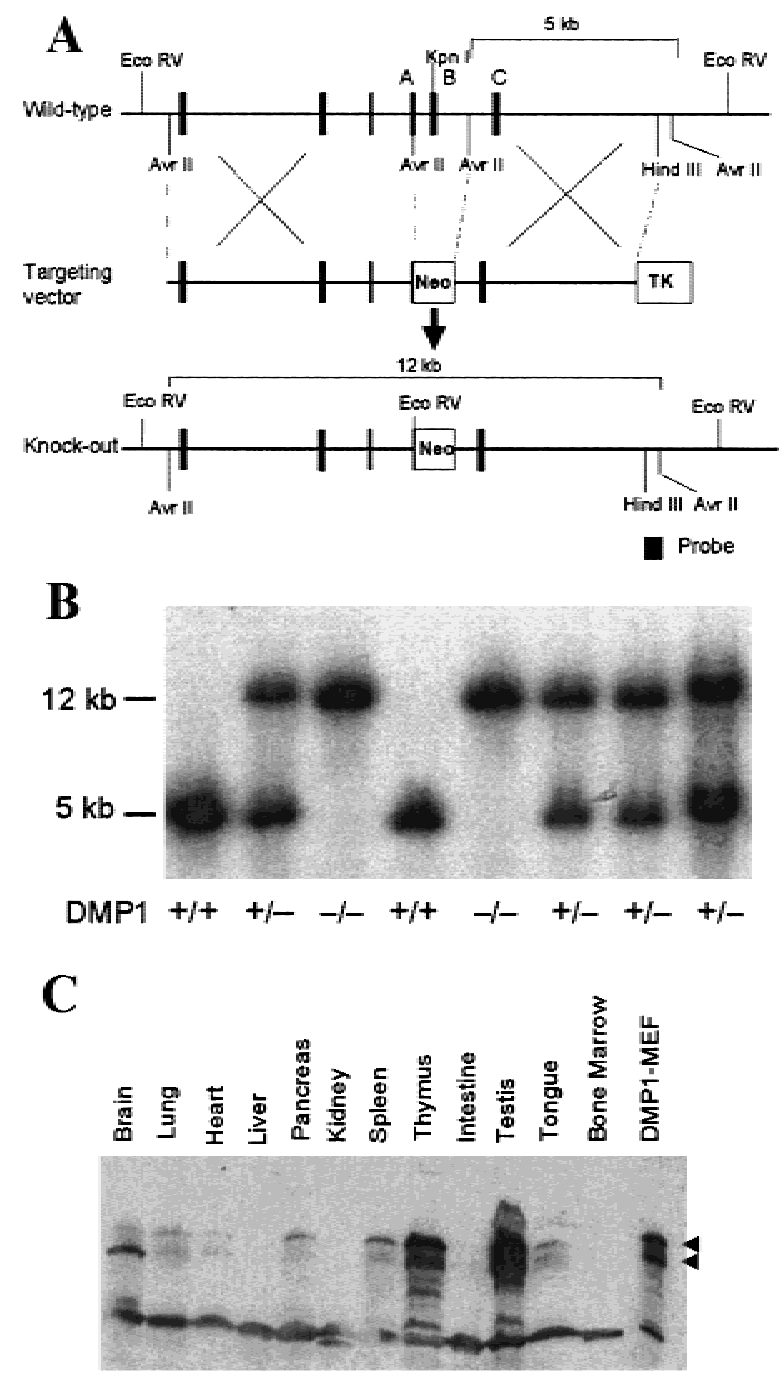

Figure 1. Targeted disruption of DMP1 in mice and expression of DMP1 protein in tissues. (A) Schematic representations of a portion of the murine DMP1 locus (top) and the DMP1 targeting vector (middle). Solid boxes denote exons with $5^{\prime}$ ends to the left. AvrII sites important for analysis of deletions are indicated. When genomic DNA is digested with AvrII and hybridized with the HindIII-AvrII probe, the wild-type locus yields a 5-kb band and the targeted locus (bottom) produces a 12-kb fragment. (B) Southern blot analysis of tail DNAs from $\mathrm{F}_{2}$ animals. The sizes of AvrII fragments are indicated. (C) Tissue distribution of DMP1 protein in an 8-week-old mouse. A lysate from wild-type MEFs infected with full-length DMP1 virus was used as a positive control. The sources of tissues are indicated at the top; arrowheads at right indicate the positions of differentially phosphorylated DMP1 isoforms (Hirai et al. 1996).

died before they could be genotyped. We noted that DMP1-null animals were small at birth and developed more slowly than their littermates, this being more obvious in males than in females (Fig. 2). Prospective studies revealed that about one-third of the $D M P 1^{-/-}$mice died in the first 3 weeks of life. We found no obvious anatomic abnormalities in these animals, except that their stomachs were devoid of milk, suggesting that they could not compete with their littermates for nourishment. During the interval in which surviving DMP1-null animals developed to 8 weeks of age, the males remained $19 \% \pm 4 \%$ smaller than their littermates, whereas the body weights of $D M P 1^{-/-}$females were not significantly different from age-matched controls. Approximately $10 \%$ of $D M P 1^{-/-}$animals $>3$ months of age exhibit abnormal clasping reflexes when raised by their tails and experience occasional seizures. Pathologic examination has not revealed any specific lesions that would account for the incompletely penetrant neurologic phenotype. Approximately one-third of the DMP1-null males also develop a chronic obstructive uropathy characterized by genital swelling, dilated seminal vesicles, and distension of the urinary bladder. The cause remains unclear, although the syndrome is characteristically observed in a number of inbred mouse strains (Babcock and Southam 1965; Gaillard 1999).

\section{ARF accumulation and cell growth control are compromised in $\mathrm{DMP}^{-1-}$ MEFs}

DMP1 binds to a canonical recognition site in the murine $A R F$ promoter to activate gene expression, and the induced ARF protein, in turn, causes p53-dependent cell cycle arrest. Neither p19 ${ }^{\mathrm{ARF}}$ nor p16 $6^{\mathrm{INK} 4 \mathrm{a}}$ appear to be expressed during mouse embryonic development, but when embryos are explanted into culture both proteins are induced and steadily accumulate as MEFs are passaged and their growth rate progressively diminishes (Zindy et al. 1997, 1998). Loss of $A R F$ alone prevents the replicative growth arrest typical of wild-type cells and enables explanted MEFs to proliferate continuously; these apparently immortal fibroblasts can be transformed by oncogenic Ras without the requirement for an

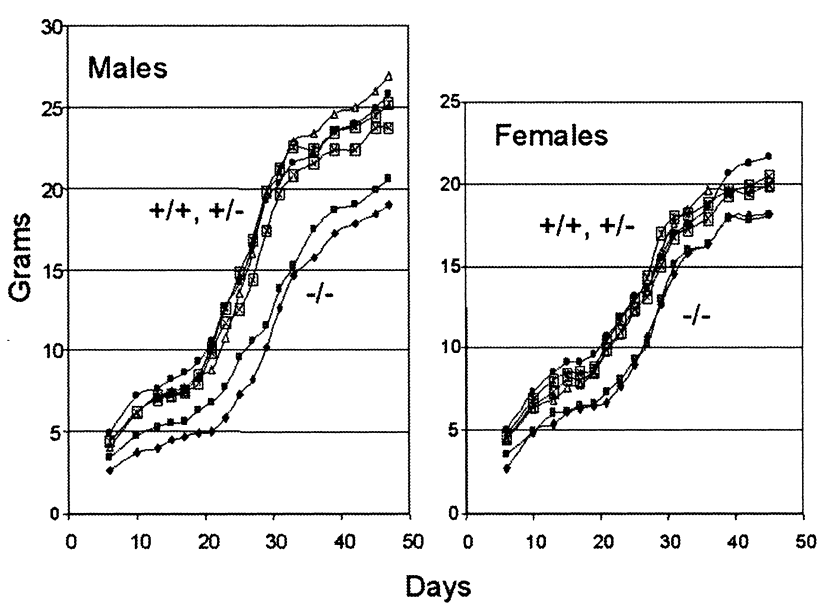

Figure 2. Growth of neonatal $D M P 1^{-/-}, D M P 1^{+/-}$, and $D M P 1^{+/+}$mice. The body weights of littermates were measured every 2-3 days. DMP1-/- mice were $20 \%-30 \%$ smaller than their control littermates at birth. Male $D M P 1^{-/-}$mice remained smaller even as adults; female knockout mice eventually became indistinguishable from their $D M P 1^{+/+}$or $D M P 1^{+/-}$littermates. 
"immortalizing oncogene," such as Myc or adenovirus E1A (Kamijo et al. 1997). Because DMP1-induced MEF growth arrest is $A R F$ dependent, we assessed p19 $9^{\mathrm{ARF}}$ expression and the proliferative behavior of MEFs explanted from DMP1-null embryos.

Genotyped MEFs passaged in vitro on defined 3T3 or 3T9 protocols (see Materials and Methods) were assayed at early passage for both $\mathrm{p} 19^{\mathrm{ARF}}$ and $\mathrm{p} 16^{\mathrm{INK} 4 \mathrm{a}}$ protein expression. In wild-type 3 T9 strains established from different embryos [e.g., 3T9 clones designated 44 and 47 (Fig. 3)], both proteins accumulated between culture passages 2 and 7. However, in $D M P 1^{-/-}$MEFs (e.g., 3T9 clones 23 and 26), p19 ARF accumulation was retarded, and peak levels were significantly reduced to $20 \%-40 \%$ of those detected in age-matched wild-type cells. On the other hand, p16 $6^{\text {INK4a }}$ accumulation was not altered significantly in early-passage DMP1-null MEFs. When the same filter was probed with antibodies to DMP1, the protein was observed to be abruptly induced in both $D M P 1^{+/+}$and $D M P 1^{+/-}$cells between passages 2 and 3, after which the levels appeared to decline.

We undertook a more comprehensive study of MEFs explanted from individual embryos and passaged on a 3T3 protocol (Table 1). Under this regimen, $D M P 1^{+/+}$ MEFs initially underwent two to three population doublings in the first 3 days prior to dilution and replating, but their growth rate diminished and virtually ceased by passage 10 (Fig. 4A,B). As is characteristic of so-called senescent populations, many cells in these cultures ap-

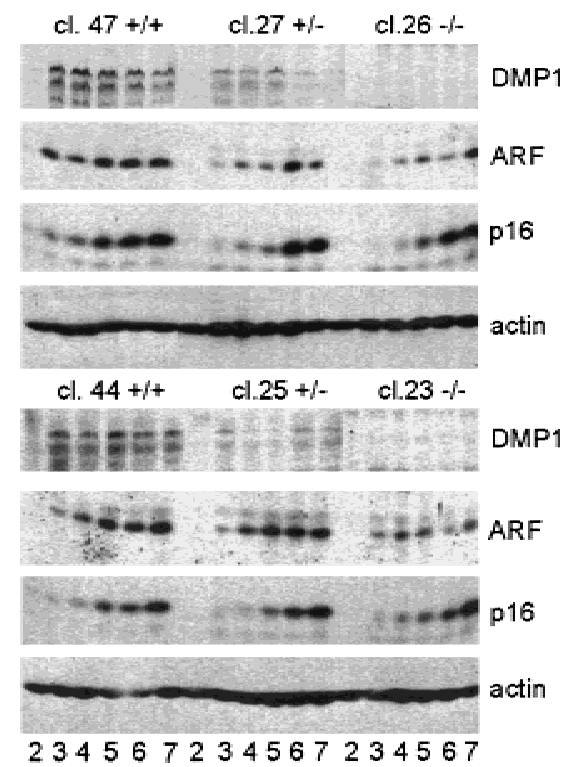

Figure 3. Expression of DMP1, p19 ARF, and $\mathrm{p} 16^{\mathrm{INK} 4 \mathrm{a}}$ proteins in MEFs of different genotypes. Genotyped MEFs, as indicated at the top of each panel, were passaged following a 3T9 protocol, and cell pellets were collected at each passage. Proteins were extracted and sonicated in buffer containing $0.5 \%$ NP-40 and protease inhibitors, and DMP1, p19 ${ }^{\mathrm{ARF}}, \mathrm{p} 16^{\mathrm{INK} 4 \mathrm{a}}$, and actin levels were determined by direct immunoblotting with antibodies to the indicated proteins. Representative results from two different clones with each genotype are shown. Early-passage levels from 2 to 7 are indicated at the bottom. peared large, flat, and nonrefractile (Fig. 4C, top). In contrast, $D M P 1^{-/-}$MEFs grew faster than their wild-type counterparts, yielding more cells at each passage prior to redilution (Fig. 4A,B). By passage 10, DMP1-null cells doubled only once per 2-3 days, but they remained in cycle (Fig. 4B). Unlike senescent wild-type MEFs, the $D M P 1$-null cells remained smaller and more refractile with much fewer giant cells (Fig. 4C, bottom). Cells maintained on a 3T9 protocol, although passaged at higher density, exhibited similar characteristics, with the DMP1-null cells always exhibiting a proliferative advantage and not exiting cycle (data not shown).

At later passages (Fig. 4A; Table 1), variants with increased proliferative potential emerged from both wildtype and DMP1-null 3T3 and 3T9 cultures, and these could be continuously propagated as established cell lines. In previous studies it was found that $\sim 80 \%$ of spontaneously immortalized 3T3 cell lines contain mutant forms of p53, whereas the remainder generally sustain biallelic deletions of ARF (Harvey and Levine 1991; Kamijo et al. 1997; Zindy et al. 1997, 1998). An as yet unexplained distinguishing feature is that cells lacking functional p53 are genetically unstable and spontaneously generate variants with increased ploidy, whereas those lacking $A R F$ tend to remain pseudodiploid (Kamijo et al. 1997; Levine 1997; Zindy et al. 1997) unless challenged with microtubule inhibitors (Khan et al. 2000). In the present series of experiments, five of six lines arising from $D M P 1^{+/+}$MEF strains and three of three lines derived from $D M P 1^{+/-}$cells contained mutant forms of p53 and yielded hyperdiploid or tetraploid variants upon establishment; one $D M P 1^{+/+}$line underwent INK4a-ARF loss as demonstrated by Southern blotting analysis. In cells sustaining inactivating p53 mutations, the altered p53 protein is transcriptionally unable to activate its negative regulator $\mathrm{Mdm} 2$ and therefore accumulates to unusually high levels (Fig. 5A, e.g., DMP1 ${ }^{+/+}$clone 19) (Barak et al. 1993; Wu et al. 1993; Haupt et al. 1997; Kubbutat et al. 1997; Midgley et al. 1997); p19 ARF expression is also elevated in these cells (Fig. 5A, clone 19), due to loss of the p53-p19 ${ }^{\mathrm{ARF}}$ negative feedback loop (Kamijo et al. 1998; Stott et al. 1998). Similar results were observed with lines derived from other $D M P 1^{+/+}$embryos (Table 1).

It should be noted that $\mathrm{p} 16^{\mathrm{INK} 4 \mathrm{a}}$ had no apparent role in the establishment of mouse 3T3 or 3T9 cell lines (Kamijo et al. 1997). As observed previously (Zindy et al. 1997), p16 ${ }^{\text {INK4a }}$ was induced when MEFs were explanted into culture, and its levels rose progressively as either $D M P 1^{+/+}$or $D M P 1^{-/-}$cells were passaged (Fig. 3). The levels of $\mathrm{p} 16^{\mathrm{INK} 4 \mathrm{a}}$ were maximal by passages $10-15$, being about twofold higher than those at passage 7 , after which they remained fixed and elevated. Consistent with previous findings, equally high levels of $\mathrm{p} 16^{\mathrm{INK} 4 \mathrm{a}}$ continued to be expressed in established lines arising from either $D M P 1^{+/+}$or $D M P 1^{-/-}$embryos (data not shown).

In contrast, when $D M P 1^{-/-}$MEFs were maintained in culture, lines derived from individual embryos continued to express unusually low levels of p19 ${ }^{\mathrm{ARF}}$, and p53 
Table 1. Characteristics of MEFs passaged on a $3 T 3$ protocol

\begin{tabular}{|c|c|c|c|c|c|c|c|}
\hline $\begin{array}{l}\text { Clone } \\
\text { no. }\end{array}$ & Genotype & Establishment $^{\mathrm{a}}$ & $\begin{array}{c}\text { DNA } \\
\text { content }^{\mathrm{b}}\end{array}$ & $\begin{array}{l}\text { ARF } \\
\text { level }\end{array}$ & $\begin{array}{l}\text { p53 } \\
\text { level }\end{array}$ & p53 isoform ${ }^{c}$ & $\begin{array}{c}\text { IR } \\
\text { response }^{c}\end{array}$ \\
\hline 4 & $+/+$ & P18 & $\mathrm{D}+\mathrm{HD}$ & high & very high & mutant (P30) & N.D. \\
\hline 19 & $+/+$ & $\mathrm{P} 24$ & $\mathrm{~T}$ & high & very high & mutant (P29) & N.D. \\
\hline 48 & $+/+$ & P20 & $\mathrm{T}$ & very high & null & N.D. & N.D. \\
\hline 49 & $+/+$ & P20 & $\mathrm{D}+\mathrm{T}$ & high & very high & N.D. & defective \\
\hline 50 & $+/+$ & P16 & $\mathrm{D}+\mathrm{HD}$ & null & low & N.D. & N.D. \\
\hline 51 & $+/+$ & P20 & $\mathrm{D}+\mathrm{T}$ & high & high & mutant (P28) & defective \\
\hline 15 & $+1-$ & P16 & $\mathrm{T}$ & very high & very high & N.D. & N.D. \\
\hline 21 & $+/-$ & P24 & $\mathrm{T}$ & very high & very high & N.D. & N.D. \\
\hline 43 & $+1-$ & $\mathrm{P} 23$ & $\mathrm{~T}$ & very high & very high & mutant (P30) & defective \\
\hline 1 & $-1-$ & P16 & $\mathrm{D}$ & low & low & N.D. & intact (P44) \\
\hline 14 & $-1-$ & P17 & $\mathrm{D}$ & low & low & N.D. & intact (P54) \\
\hline 16 & $-1-$ & N.Det. & $\mathrm{D}$ & very low & low & wild type (P20) & N.D. \\
\hline 17 & $-1-$ & P13 & $\mathrm{D}$ & low & low & $\operatorname{mixed}(\mathrm{P} 35)^{\mathrm{d}}$ & N.D. \\
\hline 22 & $-1-$ & P22 & D & low & low & N.D. & intact (P54) \\
\hline 23 & $-1-$ & P17 & $\mathrm{D}+\mathrm{HD}$ & low & low & wild type (P27) & N.D. \\
\hline 26 & $-1-$ & P18 & $\mathrm{D}$ & low & low & wild type (P30) & N.D. \\
\hline 28 & $-1-$ & P18 & $\mathrm{D}+\mathrm{HD}$ & low & low & $\operatorname{mixed}(\mathrm{P} 27)^{\mathrm{d}}$ & N.D. \\
\hline 29 & $-1-$ & N.Det. & $\mathrm{D}$ & medium & low & wild type (P35) & intact (P33) \\
\hline 30 & $-1-$ & P25 & $\mathrm{D}+\mathrm{HD}$ & low & low & wild type (P35) & intact (P33) \\
\hline 37 & $-1-$ & N.Det. & $\mathrm{D}$ & low & low & wild type (P25) & N.D. \\
\hline 38 & $-1-$ & $\mathrm{P} 23$ & HD & low & low & wild type (P30) & N.D. \\
\hline 41 & $-1-$ & N.Det. & $\mathrm{D}$ & low & low & wild type (P30) & intact (P28) \\
\hline 42 & $-1-$ & P18 & HD & low & low & wild type (P25) & N.D. \\
\hline
\end{tabular}

${ }^{a}(\mathrm{P})$ Passage level at which cells resume growth and exhibit more than one population doubling per 3 days. (N.Det.) Not determined; proliferation of these lines was never significantly retarded.

b(D) Diploid; (HD) hyperdiploid; (T) tetraploid.

c(P) Passage number at which the indicated assay was performed. (N.D.) Not done.

${ }^{\mathrm{d}}$ (Mixed) These clones eventually contained a mixture of both wild-type and mutant p53 isoforms. The mutant form represented a minor fraction, so that the overall p53 levels remained low.

levels were not elevated (Table 1; see Fig. 5A, clones 14, 16, and 22 for representative data). The levels of Mdm2 in $D M P 1^{-/-}$MEFs were somewhat lower than those in wild-type cells and were not maintained on prolonged passage (Fig. 5A). Therefore, Mdm2 overexpression did not account for the ability of these cells to continue to proliferate. The majority of the DMP1 $1^{-1-}$ cells retained a diploid DNA content when assayed both karyotypically and by FACs, and although some were hyperdiploid, tetraploidy was not observed (Table 1). We examined chromosomes in nine diploid $D M P 1^{-/-}$cell lines by use of FISH analysis performed with a $\mathrm{P} 1$ phage that includes the INK4A-ARF locus (data not shown). This revealed two copies of the complementary segment in eight lines and a single copy in one line (Table 1; one copy of $A R F$ was deleted in clone 22 after passage 40 ). To confirm that late-passage $D M P 1^{-/-}$cells had intact $A R F$ function, we infected cells from seven independently derived strains (including clone 17, which expressed mutant p53; see below) with a retrovirus encoding a tamoxifen-inducible DMP1-ER protein (Inoue et al. 1999). Cells were pulse labeled for $3 \mathrm{hr}$ with BrdU prior to induction, and parallel cultures were similarly labeled $48 \mathrm{hr}$ after 4-hydroxytamoxifen treatment. DMP1 induction reduced the S-phase fraction by $>70 \%$ in all MEF strains that expressed wild-type p53 but had no effect on the one strain that expressed mutant $\mathrm{p} 53$. Thus, whereas $\mathrm{p} 19^{\mathrm{ARF}}$ levels remained low in late-passage DMP1-null cells, restoration of DMP1 induced p53-dependent cell cycle arrest.

The use of isoform-specific antibodies that discriminate between wild-type and mutant p53 conformations confirmed that p53 was not mutated in late-passage (p20-p35) DMP1-1- cells (Fig. 5B; Table 1). To test whether p53 was functional, the cells were exposed to ionizing radiation and assayed for p53 and $\mathrm{Mdm} 2$ proteins. All DMP1 $1^{-/-}$MEF clones tested (Table 1) exhibited the characteristically rapid accumulation of p53 and Mdm2 after irradiation, whereas established cell lines derived from $D M P 1^{+/+}$and $D M P 1^{+/-}$MEFs that had constitutively high levels of mutant p53 lacked an Mdm2 response (Fig. 5C). By these criteria, functional p53 was maintained in the $D M P 1^{-/-}$lines after many passages (Table 1). Two of $14 D M P 1^{-/-}$cell lines (clones 17 and 28 , Table 1) that initially behaved like the others accumulated noticeably higher levels of p53 and p19 $9^{\mathrm{ARF}}$ at later passages and eventually yielded tetraploid subpopulations, suggesting that a fraction of these cells had sustained p53 mutations. This was confirmed using isoform-specific antibodies - an underrepresented band corresponding to mutant p53 was observed in extracts of clone 28 MEFs at passage 27 (Fig. 5B). Therefore, although selection for p53 mutation can occur during es- 


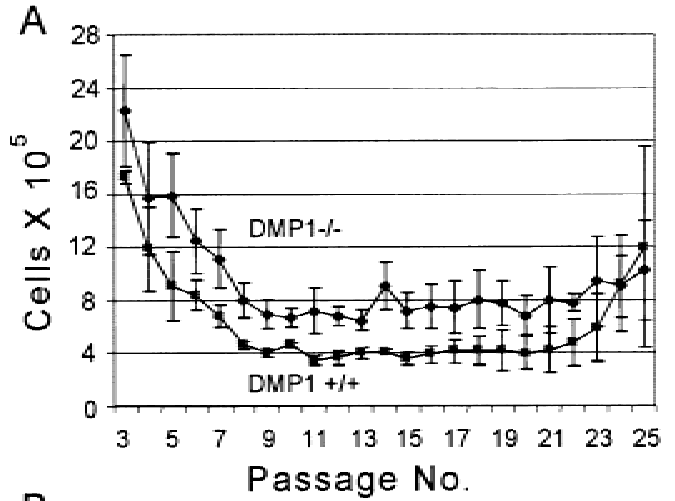

B

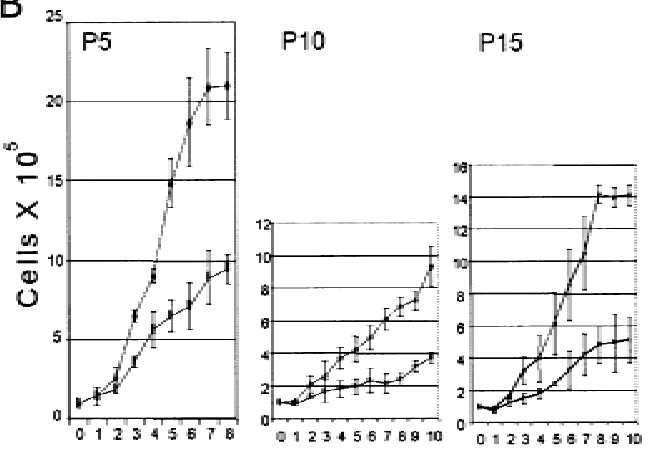

C

Days
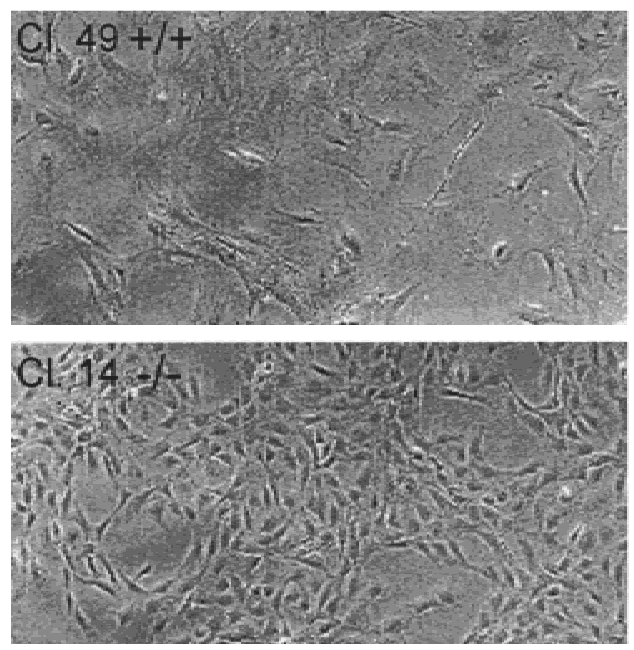

Figure 4. Growth kinetics and morphology of MEFs. (A) Cell proliferation on a $3 \mathrm{~T} 3$ protocol. At 3-day intervals, the total number of cells per $60-\mathrm{mm}$-diam. culture dish were counted prior to redilution to $3 \times 10^{5}$ per dish for the next passage. Data were plotted from four to six embryos of each genotype (see Table 1). Error bars indicate s.D. from the mean. ( $) D M P 1^{-/-}$ cells; (ロ) $D M P 1^{+/+}$cells. (B) Cells from $D M P 1^{-1-}(\downarrow)$ and $D \mathrm{MP1}^{+/+}(\square)$ MEF strains at passages 5, 10, and 15 were seeded at $1 \times 10^{5}$ cells per culture in $60-\mathrm{mm}$-diam. dishes. Duplicate cultures were harvested at daily intervals, and the total number of cells per culture were determined. Data from four to six different strains of the same genotype were pooled. Error bars indicate S.D. from the mean. (C) Photomicrographs of MEFs at passage 18. Wild-type (clone 49) MEFs were senescent; $D M P 1^{-/-}$ MEFs (clone 14) were not.

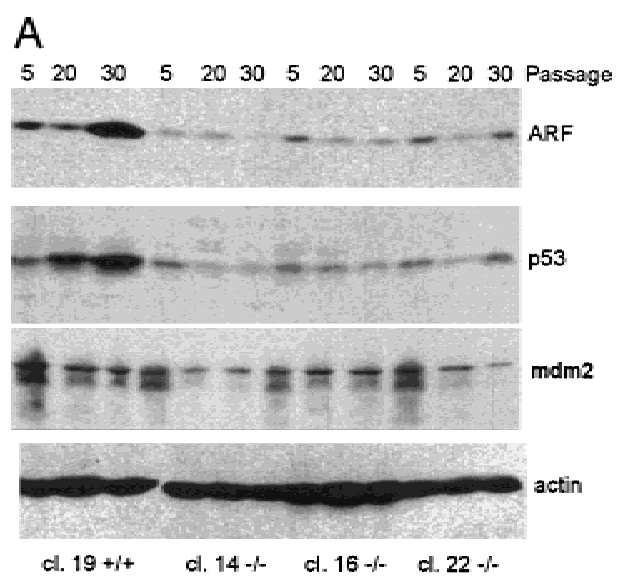

B

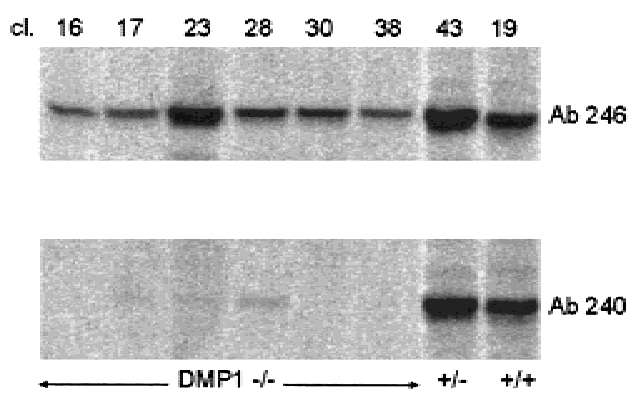

C

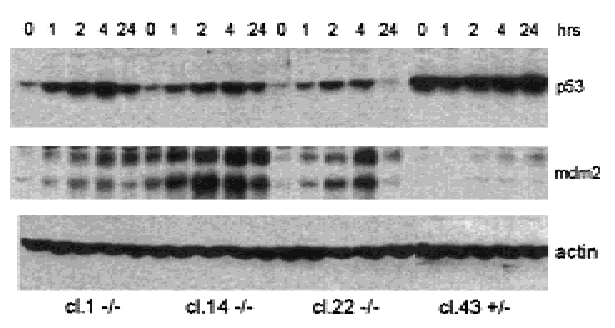

Figure 5. MEF cell lines established from $D M P 1^{-/-}$embryos retain wild-type p53. (A) Genotyped MEFs (as indicated at the bottom) were passaged on a 3T3 protocol. p19 ${ }^{\mathrm{ARF}}, \mathrm{p} 53$, and $\mathrm{Mdm} 2$ expression were determined from cell lysates prepared at passages 5, 20, and 30 (indicated at the top) using actin as a control for protein loading. (B) Immunoprecipitation of metabolically labeled p53 proteins with isoform-specific antibodies. Lysates from eight MEF clones (top) harvested 5-10 passages postestablishment after metabolic labeling with $\left[{ }^{35} \mathrm{~S}\right] \mathrm{methio-}$ nine were immunoprecipitated with specific monoclonal antibodies to wild-type (Ab 246) or mutant (Ab 240) p53 protein. Established clones from $D M P 1^{+/+}$or $D M P 1^{+/-}$embryos (genotypes indicated at bottom) generally produced both mutant and wild-type p53 proteins; five of six randomly chosen clones from $D M P 1^{-1-}$ embryos synthesized only wild-type p53. DMP1-/clone 28 contained a minor population of cells synthesizing mutant p53. (C) Induction of p53 and Mdm2 in irradiated MEF cell lines. Established MEF cell lines (genotypes indicated at bottom) were irradiated (10Gy) and cultured for the times (hr) indicated at the top. Cell lines from $D M P 1^{-/-}$MEFs (clones 1, 14 , and 22) showed rapid accumulation of both p53 and Mdm2 following exposure to ionizing radiation; a $D M P 1^{+/-}$line (clone 43) containing high levels of mutant p53 showed a minimal Mdm2 response. 
tablishment of $D M P 1^{-/-}$cell lines, the frequency of these events (only $14 \%$ in this series) is significantly less than that observed with wild-type MEFs. DMP1-/- cells therefore have an extended life span in culture without inactivating ARF or p53.

\section{Transformation of $\mathrm{DMP}^{-/-}$MEFs with oncogenic Ras}

In wild-type MEFs constitutive signaling by oncogenic Ras provokes cell-cycle arrest with up-regulation of p16 ${ }^{\text {INK4a }}$, p19 ${ }^{\mathrm{ARF}}$, and p53 (Lloyd et al. 1997; Serrano et al. 1997; Sewing et al. 1997; Palmero et al. 1998; Zhu et al. 1998). In contrast, INK4a-ARF- or ARF-null MEFs do not undergo replicative arrest and are transformed by oncogenic Ras without any requirement for collaborating immortalizing oncogenes (Serrano et al. 1996; Kamijo et al. 1997). When early-passage (p3) MEFs were infected with retroviruses encoding oncogenic Ha-Ras (Val-12), multiple foci of transformed cells were detected in $D M P 1^{-/-}$but not in $D M P 1^{+/+}$MEFs (Fig. 6A). We obtained $30 \pm 10$ foci per $100-\mathrm{mm}$-diam. plate in each of two experiments performed with three different $D M P 1^{-1-}$ MEF strains. The transformation frequency was at least $0.3 \%$ (see Fig. 6, legend), whereas no foci were observed with wild-type cells (transformation frequency $<0.01 \%$ ). Morphologically, the transformed cells were highly refractile, no longer contact inhibited (Fig. $6 \mathrm{~B}$, bottom panels), and able to form colonies in agar at cloning efficiencies of $2 \%-10 \%$ (data not shown). We assayed the levels of $\mathrm{p} 19^{\mathrm{ARF}}, \mathrm{p} 53$, and $\mathrm{p} 16^{\mathrm{INK} 4 \mathrm{a}}$ in earlypassage MEFs of different genotypes following acute in- fection with the Ha-Ras retrovirus. Expression of all three proteins was severely compromised in $D M P 1^{-/-}$ cells, despite equivalent levels of p21 Ras (Fig. 6C). The blunted $\mathrm{p} 16^{\text {INK4a }}$ response to Ha-Ras (Val-12) was a common but unexplained feature. Collectively, these data indicate that cells lacking functional DMP1, like those lacking ARF or p53, are susceptible to transformation by oncogenic Ras.

\section{Enhanced proliferation of DMP1-null T cells}

Because DMP1 protein expression is high in the thymus, we assessed the proliferative capacity of lymphocytes isolated from $D M P 1^{-/-}$and $D M P 1^{+/+}$animals. The numbers of thymocytes in organs of $D M P 1^{-/-}$mice were $35 \% \pm 5 \%$ of those in control $D M P 1^{+/+}$animals, whereas splenocyte numbers were reduced by $50 \% \pm 5 \%$. This was likely because $D M P 1^{-/-}$animals were smaller than $D M P 1^{+/+}$animals within the first 8 weeks of life (Fig. 2). No significant differences were found between $D M P 1^{+/+}$ and $D M P 1^{-/-} \mathrm{T}$ lymphocytes in surface marker profile (CD4/CD8) or in the short-term proliferative responses of thymocytes and splenocytes following stimulation with anti-CD3 and IL-2 (data not shown). However, when splenic $\mathrm{T}$ lymphocytes were put into long-term culture after anti-CD3 and IL-2 stimulation, DMP1-/splenic $\mathrm{T}$ cells showed a significantly higher proliferative capacity than $D M P 1^{+/+}$controls (Fig. 7A). Following secondary stimulation, the $\mathrm{T}$ lymphocytes from $D M P 1^{-1-}$ mice showed an even more exaggerated growth advantage. Three weeks after secondary stimulation,
A

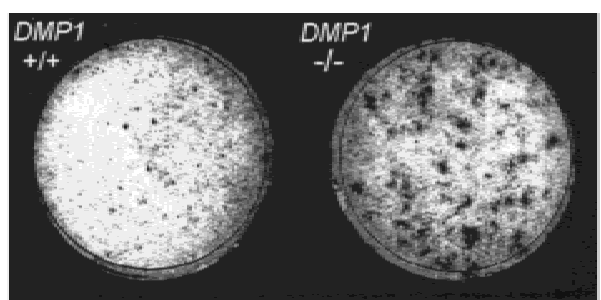

B
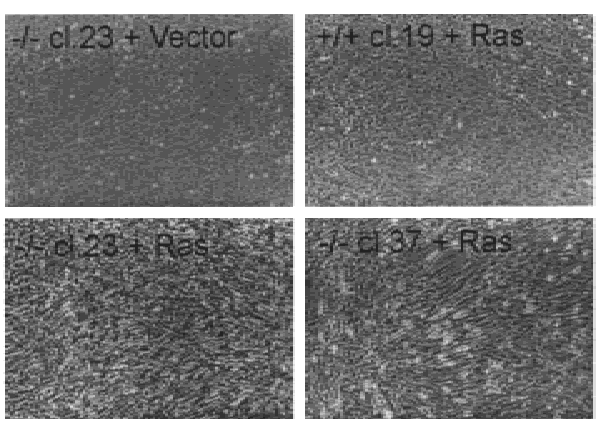

C

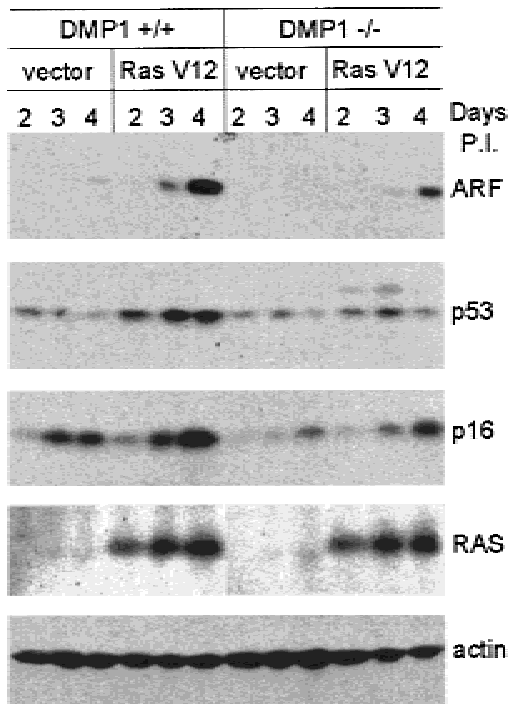

Figure 6. Early-passage $D M P 1^{-/-}$MEFs are transformed by oncogenic Ha-Ras. (A) Focus-forming assay. Genotyped MEFs (upper left) were infected with retrovirus expressing Ha-Ras (Val-12). Infected cells were selected with puromycin for 48 hr. A total of $1 \times 10^{4}$ infected cells were mixed with $3 \times 10^{5}$ uninfected cells and seeded onto $100-\mathrm{mm}$-diam. plates. Fourteen days later, transformed foci were stained with Giemsa and photographed. $(B)$ Morphology of transformed foci. Genotypes are indicated in inserts at top. Cells in the upper left panel were infected with vector; all other cells were infected with retrovirus expressing Ha-Ras (Val-12). (C) Expression of $\mathrm{p} 19^{\mathrm{ARF}}, \mathrm{p} 53, \mathrm{p} 16^{\mathrm{INK} 4 \mathrm{a}}$, and Ha-Ras proteins in virus-infected cells. Genotyped passage-3 MEFs were infected with empty vector or virus encoding Ha-Ras (Val-12), and infected cells were harvested 2, 3, and 4 days postinfection (numbers at top). Lysates were analyzed by direct immunoblotting with specific antibodies to the indicated proteins. 

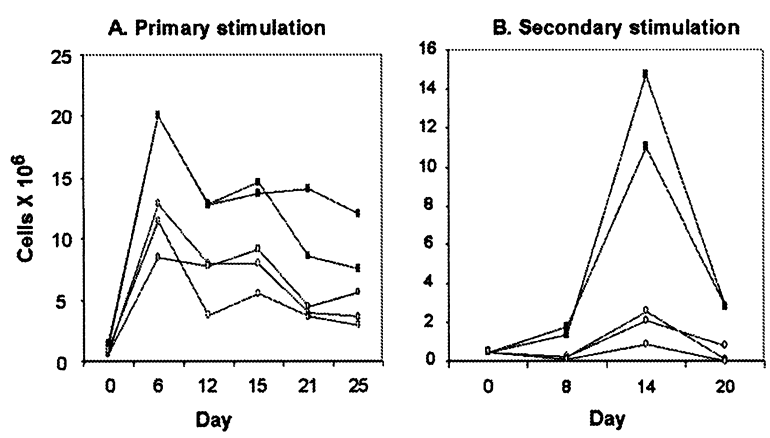

Figure 7. Growth of stimulated splenic T-lymphocytes in culture. (A) Freshly isolated $D M P 1^{-/-}(\mathbf{\square})$ and $D M P 1^{+/+}(O)$ splenic lymphocytes were stimulated with $0.25 \mu \mathrm{g} / \mathrm{ml}$ soluble anti$\mathrm{CD} 3$ and $100 \mathrm{U} / \mathrm{ml}$ human recombinant IL-2. (B) After 3 weeks of primary stimulation, the cells were restimulated with 0.25 $\mathrm{\mu g} / \mathrm{ml}$ soluble anti-CD3 and $100 \mathrm{U} / \mathrm{ml}$ human recombinant IL2. Cell numbers were determined at the indicated intervals.

nearly all $(>90 \%)$ wild-type $\mathrm{T}$ cells had died, whereas a significant fraction of $D M P 1^{-/-} \mathrm{T}$ cells were still alive (Fig. 7B). When similar experiments were performed with cells from $A R F^{-/-}$mice, their $\mathrm{T}$ lymphocytes exhibited a similar proliferative advantage after secondary stimulation with anti-CD3 and IL-2 (data not shown).

\section{Accelerated tumor formation in DMP1 nullizygous and heterozygous mice}

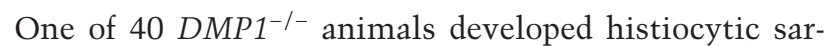
coma and 1 of $80 \mathrm{DMP1}^{+/-}$animals developed T-cell lymphoma within the first year of life, whereas no tumors were seen in 55 age-matched wild-type littermates observed for the same period. Despite the low incidence of spontaneous tumor formation, DMP1-null and heterozygous mice were unusually susceptible to tumors induced by neonatal treatment with either ionizing radiation or dimethylbenzanthracene (DMBA) (Table 2). Fifteen of $39(39 \%)$ DMBA-treated $D M P 1^{-/}$animals and 5 of $28(18 \%) D M P 1^{+/-}$mice developed tumors within 8 months after treatment, whereas no tumors were detected in the similarly treated $D M P 1^{+/+}$group (28 mice) during the same interval. Half of the tumor-bearing animals with $D M P 1^{-/-}$and $D M P 1^{+/-}$genotypes presented with multiple tumors of different histologic types. Skin tumors in the DMBA-treated groups were mostly benign squamous tumors with only two frank carcinomas; more than half of these animals also exhibited multiple bronchioalveolar adenomas. The most common cause of death in $D M P 1^{-/-}$and $D M P 1^{+/-}$mice treated with DMBA was lymphoma, which was seen in five $D M P 1^{-/-}$ $(13 \%)$ and four $D M P 1^{+/-}(14 \%)$ animals. Hemangiomas with thrombus formation and/or malignant ovarian tumors also caused deaths in these cohorts. One $D M P 1^{-/-}$ mouse with an ovarian granulosa cell tumor presented with pulmonary adenocarcinoma and skin papillomas.

Eight of $31(26 \%) D M P 1^{-/-}$mice and 4 of $35(11 \%)$ $D M P 1^{+/-}$animals that were $\gamma$-irradiated after birth developed tumors within 9 months of treatment, many of which were highly malignant T-cell lymphomas. Osteogenic and histiocytic sarcoma were observed in two of the $D M P 1^{+/-}$mice. Only one lymphoma was seen among 29 neonatally irradiated $\mathrm{DMP}^{+/+}$mice. The elevated incidence of tumors in DMP1 heterozygotes was particularly surprising. We did not observe loss of the remaining $D M P 1$ allele in three cases of lymphoma so analyzed, leaving open the possibility that DMP1 may be haploinsufficient for tumor suppression. Karyotypic analysis of four lymphomas from $D M P 1^{-/-}$or $D M P 1^{+/-}$animals revealed near diploid chromosome numbers, suggesting that p53 function might have been retained in these tumors. We conclude that in the face of environmental carcinogens, $D M P 1^{-/-}$animals are tumor prone.

\section{Discussion}

The p53, Bmi-1, Twist, c-Myc, E2F1, and DMP1 transcription factors regulate $A R F$ expression directly or indirectly. Cells lacking functional p53 express unusually high levels of ARF (Quelle et al. 1995), which are reduced after reintroduction of wild-type p53 (Kamijo et al. 1998; Stott et al. 1998), but the mechanism by which p53 negatively feeds back to regulate $A R F$ expression is unknown (Robertson and Jones 1998; Inoue et al. 1999). Conversely, c-Myc, E2F-1, and DMP1 activate ARF expression. Despite observations that c-Myc induces $A R F$ protein accumulation rapidly and that the $A R F$ promoter contains potential Myc-binding E-box motifs, c-Myc did not transactivate an $A R F$ promoter-reporter construct in NIH-3T3 cells (K. Inoue et al., unpubl.). In turn, Bmi-1 and Twist counteract the proapoptotic effects of Myc, and their ability to reduce $A R F$ expression impairs Myc induction of p53 target genes (Jacobs et al. 1999; Maestro et al. 1999). DMP1 and E2F family proteins are the two transcription factors thought to transactivate murine and human ARF promoters directly (Bates et al. 1998; Robertson and Jones 1998; Inoue et al. 1999). DMP1 binds to a single canonical recognition site in the proximal mouse $A R F$ promoter to activate gene expression directly, and the resulting increase in ARF protein expression causes p53-dependent cell cycle arrest (Inoue et al. 1999). We therefore speculated that one of the crucial functions of DMP1 is to activate the ARF-Mdm2-p53 pathway.

\section{DMP1 loss interferes with replicative senescence in $M E F S$}

Several new lines of evidence now support the idea that DMP1 modulates ARF function in different physiologic contexts. First, an abrupt increase in DMP1 protein levels was observed when wild-type MEFs were explanted into culture, coinciding with the induction of $\mathrm{p} 19^{\mathrm{ARF}}$. Conversely, induction of $\mathrm{p} 19^{\mathrm{ARF}}$ was compromised significantly in DMP1-null MEFs, with ARF levels rising only sluggishly upon cell passage and never achieving those typically seen in wild-type cells. Although their growth rate slowed with passage, cells derived from $D M P 1$-null embryos remained in cycle, did not assume 
Table 2. Tumor spectrum in $\mathrm{DMP}^{-/-}$and $\mathrm{DMP} 1^{+/-}$mice

\begin{tabular}{|c|c|c|c|}
\hline Treatment & Sex & Age (weeks) & Histopathology \\
\hline \multicolumn{4}{|l|}{$\overline{D M P 1^{-/-}}$} \\
\hline None & $\mathrm{F}$ & 40 & histiocytic sarcoma, brain \\
\hline DMBA & M & 11 & squamous cell papilloma + pulmonary adenoma (2) \\
\hline DMBA & M & 13 & keratoacanthoma \\
\hline DMBA & $\mathrm{M}$ & 13 & keratoacanthoma + pulmonary adenoma (4) \\
\hline DMBA & M & 17 & T-cell lymphoma + pulmonary adenoma (2) \\
\hline DMBA & $\mathrm{F}$ & 18 & basal squamous tumor of skin + pulmonary adenoma (2) \\
\hline DMBA & M & 19 & pulmonary adenoma $(3)$ \\
\hline DMBA & M & 19 & cavernous hemangioma \\
\hline DMBA & M & 22 & T-cell lymphoma \\
\hline DMBA & M & 22 & squamous cell carcinoma and skin papilloma + sebaceous gland adenoma \\
\hline DMBA & $\mathrm{F}$ & 25 & T-cell lymphoma \\
\hline DMBA & $\mathrm{F}$ & 26 & T-cell lymphoma + pulmonary adenoma $(2)$ \\
\hline DMBA & $\mathrm{F}$ & 26 & $\begin{array}{l}\text { Ovarian granulosa cell tumor + pulmonary adenocarcinoma + squamous } \\
\text { cell papilloma }(2)\end{array}$ \\
\hline DMBA & $\mathrm{F}$ & 26 & ovarian granulosa cell tumor + hemangioma + pulmonary adenoma (2) \\
\hline DMBA & $\mathrm{F}$ & 29 & ulcerative basal cell carcinoma of skin + pulmonary adenoma (4) \\
\hline DMBA & $\mathrm{F}$ & 33 & T-cell lymphoma \\
\hline $\mathrm{X}$ ray & $\mathrm{F}$ & 25 & T-cell lymphoma \\
\hline $\mathrm{X}$ ray & $\mathrm{F}$ & 25 & T-cell lymphoma \\
\hline $\mathrm{X}$ ray & M & 27 & T-cell lymphoma \\
\hline $\mathrm{X}$ ray & M & 28 & disseminated lymphoblastic lymphoma, unknown type \\
\hline $\mathrm{X}$ ray & M & 29 & T-cell lymphoma + pulmonary adenoma \\
\hline $\mathrm{X}$ ray & $\mathrm{F}$ & 31 & T-cell lymphoma \\
\hline $\mathrm{X}$ ray & $\mathrm{F}$ & 35 & T-cell lymphoma \\
\hline $\mathrm{X}$ ray & $\mathrm{M}$ & 39 & B-cell lymphoma + pulmonary adenoma \\
\hline \multicolumn{4}{|r|}{ 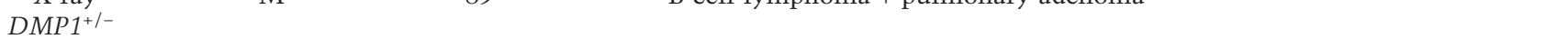 } \\
\hline None & M & 48 & T-cell lymphoma \\
\hline DMBA & $\mathrm{M}$ & 20 & T-cell lymphoma \\
\hline DMBA & M & 22 & keratoacanthoma \\
\hline DMBA & $\mathrm{F}$ & 24 & B-cell lymphoblastic lymphoma + pulmonary adenoma \\
\hline DMBA & $\mathrm{F}$ & 27 & T-cell lymphoma + keratoacanthoma + pulmonary adenoma \\
\hline DMBA & $\mathrm{F}$ & 30 & $\begin{array}{l}\text { T-cell lymphoma + ovarian granulosa cell tumor + squamous cell papilloma } \\
\quad+\text { pulmonary adenoma }(3)\end{array}$ \\
\hline $\mathrm{X}$ ray & $\mathrm{M}$ & 33 & metastatic osteogenic sarcoma \\
\hline $\mathrm{X}$ ray & $\mathrm{F}$ & 34 & histiocytic sarcoma \\
\hline $\mathrm{X}$ ray & $\mathrm{F}$ & 34 & disseminated lymphoblastic lymphoma, unknown type \\
\hline $\mathrm{X}$ ray & $\mathrm{F}$ & 35 & T-cell lymphoma \\
\hline
\end{tabular}

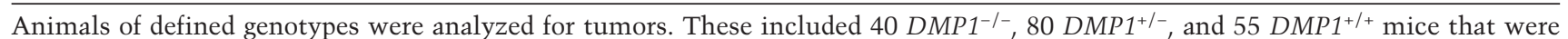

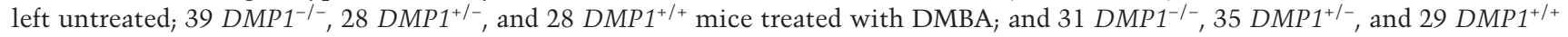
mice treated with ionizing radiation. Animals were observed for tumor development for up to 1 year of age.

the flat morphology typical of senescent populations, and expressed lower levels of p53 than age-matched wild-type populations. With further propagation, their growth rate increased again, suggesting that the cells may have adapted to continuous culture by acquiring additional mutations. However, unlike established cell lines arising from wild-type MEF strains, DMP1-null cell lines neither sustained $A R F$ deletions nor exhibited the high frequency of $p 53$ mutations $(\sim 80 \%)$ that characterize the establishment of "wild-type" 3T3 and 3T9 cell lines. Immunoprecipitation of metabolically labeled cellular proteins with isoform-specific antibodies confirmed the presence of wild-type, but not mutant, p53 in 9 of 11 DMP1-null 3T3 cell lines tested, and immunoblotting revealed that the p53 response to DNA damage induced by ionizing radiation was intact in 6 of 6 DMP1null lines long after establishment. It should be noted, however, that $A R F$ loss desensitizes cells to ionizing ra- diation by shortening the longevity of the p53 response, possibly by allowing a higher proportion of $\mathrm{p} 53$ to be neutralized by Mdm2 (De Stanchina et al. 1998; Khan et al. 2000). Using these combined criteria, 12 of 14 $D M P 1^{-/-}$cells strains continued to proliferate and maintained wild-type $p 53$ through as many as $50-100$ population doublings, whereas those from $D M P 1^{+/+}$embryos senesced after 15-20 population doublings and yielded established lines that frequently contained mutant p53. Therefore, the compromised activation of the ARFMdm2-p53 pathway in DMP1-null MEFs enabled them to bypass senescence without disrupting ARF or p53 function per se.

The kinetics of proliferation of DMP1-null cells maintained on $3 \mathrm{~T} 3$ or $3 \mathrm{~T} 9$ protocols suggest that other stochastic events may contribute to the establishment of derivative cell lines. We do not know what other genes may be involved in this process. Modest reduction in 
the expression of $\mathrm{p} 16^{\mathrm{INK} 4 \mathrm{a}}$ in Ha-Ras-producing DMP1null MEFs raises the possibility that either DMP1 or the ARF-Mdm2-p53 pathway regulates INK4a positively. However, cells lacking ARF or p53 but retaining INK4a are resistant to DMP1-induced growth arrest, implying that DMP1 does not regulate INK4a directly (Inoue et al. 1999). Moreover, high levels of p16 ${ }^{\text {INK4a }}$ expression are sustained in ARF-null populations (Kamijo et al. 1998) and in established DMP1-null 3T3 cell lines. DMP1 protein was not induced by enforced overexpression of oncogenic Ha-Ras or c-Myc (K. Inoue et al., unpubl.), indicating that $D M P 1$ does not itself respond to the same hyperproliferative signals that induce $A R F$. Conceivably, a physiological role of DMP1 might be to help set basal p19 ARF levels in the absence of oncogenic stress.

D-type cyclins interact physically and selectively with DMP1, preventing its binding to DNA and canceling its transcriptional activity (Hirai and Sherr 1996; Inoue and Sherr 1998). Thus, when overexpressed, D-type cyclins can override the ability of DMP1 to induce cell cycle arrest. Although these connections are intriguing, as yet we have no data supporting the notion that D-type cyclins regulate DMP1 in a physiologic setting in which neither protein is overexpressed. Still, the results suggest that DMP1 could functionally connect the activities of D-type cyclins and p19 $9^{\mathrm{ARF}}$ in a manner that bypasses the $\mathrm{Rb}-\mathrm{E} 2 \mathrm{~F}$ pathway. In principle, D-type cyclin overexpression could provide both positive (activation of E2F) and negative (cancellation of DMP1) signals for ARF regulation.

\section{DMP1: cell transformation and tumor formation}

When DMP1-null MEFs were infected with viruses encoding oncogenic Ha-Ras, they formed numerous transformed foci. In wild-type MEFs, oncogenic Ras leads to the accumulation of a number of inhibitors of cell cycle progression, including p53, p19 $\mathrm{ARF}$, and the CDK inhibitors $\mathrm{p} 21^{\mathrm{Cip} 1}$ and $\mathrm{p} 16^{\mathrm{INK} 4 \mathrm{a}}$, and these contribute to premature replicative arrest (Lloyd et al. 1997; Serrano et al. 1997; Sewing et al. 1997; Palmero et al. 1998; Zhu et al. 1998). However, p21 Cip1 -null MEFs still require p53 mutation or $A R F$ deletion to be immortalized and sensitized to Ras transformation (Pantoja and Serrano 1999), whereas DMP1-null cells do not. Unlike animals lacking $A R F$ function, DMP1-null animals did not develop tumors spontaneously at an appreciable frequency in their first year of life, but tumors appeared in animals challenged neonatally with X-rays or carcinogens. DMBA induces Ha-Ras mutations at high frequency (Quintanilla et al. 1986), and DMBA-treated DMP1-null animals showed a significant acceleration of skin tumor formation compared to wild-type littermates, tempting speculation that mutated c-Ha-Ras can cooperate with DMP1 loss to accelerate tumor formation in vivo. In this setting, the degree of skin tumor anaplasia, invasiveness, and metastasis associated with DMP1 loss was less severe than that observed in DMBA-treated $A R F$-null animals, again indicating that in the absence of DMP1, ARF is handicapped but still active.
The DMP1 gene was originally isolated from a CTLL-2 murine T-lymphocyte cDNA library, and the protein is most abundant in the thymus and testis. DMP1-null T lymphocytes in long-term culture had a proliferative advantage when stimulated by IL-2 and antibody to CD3. Moreover, most of the lethal tumors found in DMBAtreated or irradiated DMP1-null animals were aggressive T-cell lymphomas that infiltrated vital organs, including lung, liver, brain, and heart. In contrast, DMBA-treated or irradiated $A R F$-null animals primarily develop skin carcinomas or sarcomas, respectively (Kamijo et al. 1999|. Disseminated T-cell lymphomas with leukemic manifestations were also the leading cause of death in carcinogen-treated $D M P 1^{+/-}$mice. When genomic DNAs were isolated from three randomly chosen T-cell lymphomas derived from $D M P 1^{+/-}$mice, the remaining $D M P 1$ allele was retained in tumor tissue. We have not determined whether the second allele in these cases continues to encode a wild-type DNA-binding protein; hence, we cannot exclude that DMP1 is haploinsufficient for tumor suppression. Even though the CDK inhibitor $\mathrm{p} 27^{\mathrm{Kip} 1}$ is not essential for development, loss of a single Kip1 allele is sufficient to sensitize mice to tumor induction by carcinogens and provides a precedent (Fero et al. 1998). Other tumors found in DMBA-treated or irradiated $D M P 1^{-/-}$or $D M P 1^{+/-}$mice included hemangiomas, ovarian tumors, osteocytic and histiocytic sarcoma, and bronchioalveolar adenomas. We will need to follow both untreated and treated animals into their second year of life to determine more precisely the tumor spectrum and to see whether the spontaneous incidence of tumor formation eventually eclipses that of wild-type littermates. Nonetheless, given that $>70 \%$ of $A R F$-null animals succumb to spontaneously appearing tumors within their first year of life (Kamijo et al. 1999), the differences between $A R F$ and $D M P 1$ in tumor suppression are evident.

The human DMP1 gene is located on chromosome $7 \mathrm{q} 21$, which is often deleted as part of the 7q-minus and monosomy 7 abnormalities characteristic of human acute myelocytic leukemia and myelodysplastic syndromes (Bodner et al. 1999). When a series of leukemic interphase blast cells with chromosome 7 abnormalities were examined by FISH analysis with a human DMP1 probe, one allele was invariably deleted in the malignant cells, including cases in which deletions cytogenetically appeared to involve regions distal to $7 q 21$. Our findings raise the possibility that $D M P 1$ might contribute to these disorders.

\section{Materials and methods}

Targeting vector, homologous recombination, and animal breeding

Bacteriophages containing exons encoding the DMP1 Myb-like repeats were isolated from a 129/SV mouse genomic library (Stratagene no. 946305, La Jolla, CA) using a DMP1 SacI-BstBI cDNA fragment (Hirai and Sherr 1996). Restriction enzyme maps were generated after subcloning the genomic DNA into pBluescript vectors. To construct the targeting vector, a $1.5-\mathrm{kb}$ 
AvrII fragment containing exons designated A and B in Figure $1 \mathrm{~A}$ were deleted and replaced with a $1.0-\mathrm{kb}$ cassette encoding neomycin resistance (Kamijo et al. 1997). Screening of ES cell clones was performed by digestion of genomic DNA with AvrII, scoring for 5- and 12-kb fragments diagnostic of the wild-type and disrupted locus, respectively (Fig. 1B).

Homologous recombination and generation of germ-line chimeras were performed as described previously (Kamijo et al. 1997; Zindy et al. 1999), except that $2 \mu \mathrm{M}$ Gancyclovir (Cytovene-IV, Roche Laboratories, Nutley, NJ) was used instead of FIAU for selection of ES cells. Four hundred ES cell colonies doubly resistant to G418 and Gancyclovir were analyzed for homologous recombination by use of a $0.5-\mathrm{kb} H i n d I I I-A v r I I$ genomic DNA probe (Fig. 1A). Eight ES cell clones heterozygous for the disrupted allele were injected into C57BL/ 6 blastocysts as described (Kamijo et al. 1997). Male chimeras from five ES cell clones selected by agouti coat color were mated to C57BL/6 females. Germ-line transmission was obtained from two clones. $\mathrm{F}_{1}$ mice were tested for the presence of the disrupted DMP1 locus by Southern blotting of tail DNA, and hemizygous $F_{1}$ males were inbred to generate $F_{2}$ littermates used for further studies. Where indicated, groups of neonatal mice of indicated genotypes received single exposures of $4 \mathrm{~Gy}$ of ionizing radiation or DMBA 2-5 days after birth as described (Serrano et al. 1996; Kamijo et al. 1997). The St. Jude Children's Research Hospital institutional animal care and use committee approved all phases of this study. Mice were observed daily, humanely sacrificed when moribund, and maintained in accordance with the Guide for the Care and Use of Laboratory Animals.

\section{Immunocytochemical staining and histological analyses}

Whenever hematopoietic malignancies were suspected, sections of formalin-fixed, paraffin-embedded tumor tissue were stained histochemically for $\mathrm{T}$ lymphocytes, B lymphocytes, neutrophilic granulocytes, and histiocytes by the avidin-biotin complex $(\mathrm{ABC})$ method. Antigen retrieval in tissue sections was performed within a steamer (Flavor Scenter Steamer Deluxe, Black and Decker, Shelton, CT) in citrate buffer ( $\mathrm{pH}$ 6.0), prior to immunostaining on a Dako autostainer (Dako Corporation, Carpinteria, CA). Rabbit polyclonal antiserum to human T-cell CD3 (A0452, Dako) and biotinylated goat antiserum to rabbit IgG (BA-1000, Vector Laboratories, Burlingame, CA) were used sequentially. Rat monoclonal antibody to mouse B-cell CD45R/ B220 (01121A, Pharmingen, San Diego, CA) and biotinylated rabbit antiserum to rat IgG (BA-4001, Vector Laboratories) were used as first and second antibodies, respectively. Rat monoclonal antibody to mouse macrophage MAC-2 (Cederlane International, Ontario, Canada) and biotinylated rabbit antiserum to rat IgG were used to stain histiocytes, whereas rabbit antiserum to human myeloperoxidase (A398, Dako) and biotinylated goat antibody to rabbit IgG were used to visualize granulocytes. Negative controls were prepared by omitting primary antibodies and substituting isotype-matched IgGs at equivalent concentrations. ABC reaction sections were colorized in hematoxylin solution (7221, Richard Allen Scientific, Kalamazoo, MI). Sections were analyzed by light microscopy. Lymphomas were classified according to the criteria of Pattengale and Firth (1986). All other tumor sections were analyzed as described (Kamijo et al. 1999).

\section{Cells and culture conditions}

MEFs were established from 13.5-day-old embryos as previously described (Zindy et al. 1997). Cells were maintained in DMEM containing $10 \%$ FBS, $2 \mathrm{~mm}$ glutamine, $0.1 \mathrm{~mm}$ nonessential amino acids, $55 \mu \mathrm{M} 2$-mercaptoethanol, and $10 \mu \mathrm{g} / \mathrm{ml}$ gentami- cin. Cells from individual embryos were plated into two T25 flasks and incubated at $37^{\circ} \mathrm{C}$ in a $10 \%$ humidified chamber. Cells were maintained on a defined 3-day passage schedule (Todaro and Green 1963) by plating $9 \times 10^{5}$ (3T9) or $3 \times 10^{5}$ cells (3T3) in 60-mm-diam. dishes. Plating after disaggregation of embryos was considered passage 1 , and the first passage 3 days later as passage 2. Cells were counted at each passage, and the total number was calculated prior to redilution, as shown in Figure 4. Growth rates determined at passages 5, 10, and 15 (Fig. 4B) were determined by plating replicate cultures of $1 \times 10^{5}$ cells in 60 $\mathrm{mm}$-diam. culture dishes; duplicate cultures were harvested every day thereafter and cells were counted.

To propagate $\mathrm{T}$ lymphocytes, spleens from animals of the indicated genotypes (Fig. 7) were disaggregated individually through a cell strainer, and red blood cells were lysed in Gey's solution ( $\left.150 \mathrm{~mm} \mathrm{NH}_{4} \mathrm{Cl}, 10 \mathrm{~mm} \mathrm{KHCO}_{3}\right)$. Single cell suspensions from each spleen were cultured at $37^{\circ} \mathrm{C}$ for $1 \mathrm{hr}$ in $10 \mathrm{ml}$ of RPMI 1640 medium containing $0.1 \mathrm{~mm}$ nonessential amino acids, $1 \mathrm{~mm}$ sodium pyruvate, $5 \times 10^{-5} \mathrm{M} 2$-mercaptoethanol, $100 \mathrm{U} / \mathrm{ml}$ penicillin, $100 \mu \mathrm{g} / \mathrm{ml}$ streptomycin, $2 \mathrm{~mm}$ glutamine (all from GIBCO BRL, Gaithersburg, MD) to eliminate adherent macrophages attaching to the culture flask. Purified lymphocytes were removed and cultured in the same medium at $5 \times 10^{5}$ cells $/ \mathrm{ml}$ and stimulated with $0.25 \mu \mathrm{g} / \mathrm{ml}$ anti-CD3 (Pharmingen, San Diego, CA) and $100 \mathrm{U} / \mathrm{ml}$ human recombinant IL-2 (R\&D Systems, Minneapolis, MN). Cells that were continuously expanded were purified through a Ficoll gradient (Pharmacia Biotech, Sweden) every week to remove dead cells and were then reseeded at $5 \times 10^{5}$ cells $/ \mathrm{ml}$ in the same medium with $100 \mathrm{U} / \mathrm{ml} \mathrm{IL}-2$. After 3 weeks of culture, $0.5 \mathrm{ml}$ of medium containing $1 \times 10^{6}$ cells were restimulated with $0.25 \mu \mathrm{g} / \mathrm{ml}$ of

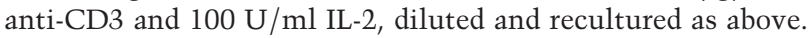

\section{Focus formation assay}

MEF cells at passages 3 to 4 were seeded at $3 \times 10^{5}$ cells $/ 100$ mm-diam. dish and cultured overnight in complete medium containing $10 \%$ FBS. MEFs were infected three times $(3 \mathrm{ml}$ each) with high-titer retrovirus stocks expressing either Ha-Ras (Val 12) or empty vector, both conferring resistance to puromycin (Zindy et al. 1998). Forty-eight hours after infection, cells were selected with $2 \mu \mathrm{M}$ puromycin for an additional $48 \mathrm{hr}$. For focus formation, $1 \times 10^{4}$ infected cells were mixed with $3 \times 10^{5}$ uninfected cells and then seeded into a $100-\mathrm{mm}$-diam. dish. Medium was changed every 3 days. Eighteen days postinfection, cells were fixed and stained with Giemsa. Assays for colony formation in soft agar were performed as described previously (Roussel et al. 1987).

\section{Protein analysis}

For analysis of DMP1, p19 ${ }^{\mathrm{ARF}}, \mathrm{p} 16^{\mathrm{INK} 4 \mathrm{~A}}, \mathrm{p} 53, \mathrm{Ha}-\mathrm{Ras}$, and actin, frozen cell pellets were dissolved in ice-cold EBC buffer [ $50 \mathrm{mM}$ Tris- $\mathrm{HCl}$ (pH 8.0), $120 \mathrm{~mm} \mathrm{NaCl}, 0.5 \%$ NP-40, 1 mM EDTA, and protease inhibitors (Hirai and Sherr 1996)] and left on ice for 1 $\mathrm{hr}$. After sonication at $4^{\circ} \mathrm{C}(7 \mathrm{sec} \times 2)$, nuclei and cellular debris were removed by centrifugation in a microcentrifuge at 15,000 rpm for $15 \mathrm{~min}$ at $4^{\circ} \mathrm{C}$. Proteins $(100 \mu \mathrm{g} /$ lane $)$ were separated electrophoretically on denaturing polyacrylamide gels containing SDS and transferred onto nitrocellulose (MSI, Westboro, MA). Sites of protein binding were visualized by direct immunoblotting with affinity-purified rabbit polyclonal antibodies to the mouse p19 ${ }^{\mathrm{ARF}}$ (Quelle et al. 1995) or DMP1 (Hirai and Sherr 1996) carboxyl termini; with mAb 2 A10 to Mdm2 provided by Dr. Gerard Zambetti (St. Jude Children's Research Hospital); or with commercial antibodies directed to p16 $6^{\text {INK4a }}$ (M-156, Santa Cruz Biotechnology, CA), p53 (Ab 7, Calbiochem, La Jolla, CA), 
Ha-Ras p21 (Ab 259, Santa Cruz Biotech.), or actin (C-11, Santa Cruz Biotech.). Labeling of MEFs with $\left[{ }^{35} \mathrm{~S}\right]$ methionine and immunoprecipitation of radiolabeled lysates with specific monoclonal antibodies to wild-type (Ab 246) (Yewdell et al. 1986) or mutant (Ab 240) p53 proteins (Gannon et al. 1990) were performed as described (Kamijo et al. 1997).

\section{Acknowledgments}

We thank Richard A. Ashmun for flow cytometric analysis and Marcus B. Valentine for karyotyping and FISH analysis of murine chromosomes; Peter McKinnon for providing ES cells and neomycin-resistant MEF cells; Scott Lowe for Ras vectors; Gerard Grosveld for assistance in generating knockout mice; Gerard Zambetti for $\mathrm{mAb} 2 \mathrm{~A} 10$; and Pim den Besten, Esther Van de Kamp, Rose Mathew, Ming Wang, Chunying Yang, and Dorothy Bush for excellent technical assistance. Thanks are extended to all other members in our laboratory for continuous encouragement and discussion throughout this work. These investigations were supported in part by NIH grants CA-71907 (M.F.R), CA-76379, and DK-44158 (J.L.C.), by Cancer Center CORE grant CA-21765, and by the American Lebanese Associated Charities of St. Jude Children's Research Hospital. C.J.S. is an investigator of the Howard Hughes Medical Institute.

The publication costs of this article were defrayed in part by payment of page charges. This article must therefore be hereby marked "advertisement" in accordance with 18 USC section 1734 solely to indicate this fact.

\section{References}

Babcock, V.I. and Southam, C.M. 1965. Obstructive uropathy in laboratory mice. Proc. Soc. Exp. Biol. Med. 120: 580-581.

Barak, Y., Juven, T., Haffner, R., and Oren, M. 1993. Mdm2 expression is induced by wild type p53 activity. EMBO $J$. 12: 461-468.

Bates, S., Phillips, A.C., Clarke, P., Stott, F., Peters, G., Ludwig, R.L., and Vousden, K.H. 1998. E2F-1 regulation of p14 ${ }^{\mathrm{ARF}}$ links pRB and p53. Nature 395: 124-125.

Bodner, S.M., Naeve, C.W., Rakestraw, K.M., Jones, B.G., Valentine, V.A., Valentine, M.B., Luthardt, F.W., Willman, C.L., Raimondi, S.C., Downing, J.R. et al. 1999. Cloning and chromosomal localization of the gene encoding human cyclin D-binding Myb-like protein (hDMP1). Gene 229: 223-228.

De Stanchina, E., McCurrach, M.E., Zindy, F., Shieh, S.Y., Ferbeyre, G., Samuelson, A.V., Prives, C., Roussel, M.F., Sherr, C.J., and Lowe, S.W. 1998. E1A signaling to p53 involves the p19 ${ }^{\text {ARF }}$ tumor suppressor. Genes \& Dev. 12: 2434-2442.

Eischen, C.M., Weber, J.D., Roussel, M.F., Sherr, C.J., and Cleveland, J.L. 1999. Disruption of the ARF-Mdm2-p53 tumor suppressor pathway in Myc-induced lymphomagenesis. Genes \& Dev. 13: 2658-2669.

El-Deiry, W.S., Tokino, T., Velculescu, V.E., Levy, D.B., Parsons, R., Trent, J.M., Lin, D., Mercer, E., Kinzler, K.W., and Vogelstein, B. 1993. WAF1, a potential mediator of p53 tumor suppression. Cell 75: 817-825.

Fero, M.L., Randel, E., Gurley, K.E., Roberts, J.M., and Kemp, C.J. 1998. The murine gene $\mathrm{p} 27^{\mathrm{Kip} 1}$ is haplo-insufficient for tumour suppression. Nature 396: 177-180.

Gaillard, E.T. 1999. Ureter, urinary bladder, and urethra. In $\mathrm{Pa}$ thology of the mouse (ed. R.R. Maronpot, G.A. Boorman, and B.G. Gaul), pp. 234-258. Cache River Press, Vienna, Illinois.

Gannon, J.V., Greaves, R., Iggo, R., and Lane, D.P. 1990. Activating mutations in p53 produce a common conformational effect: A monoclonal antibody specific for the mutant form. EMBO I. 9: 1595-1602.

Giaccia, A.J. and Kastan, M.B. 1998. The complexity of p53 modulation: Emerging patterns from divergent signals. Genes \& Dev. 12: 2973-2983.

Harbour, J.W., Luo, R.X., Dei Santi, A., Postigo, A.A., and Dean, D.C. 1999. Cdk phosphorylation triggers sequential intramolecular interactions that progressively block $\mathrm{Rb}$ functions as cells move through G1. Cell 98: 859-869.

Harvey, D.M. and Levine, A.J. 1991. p53 alteration is a common event in the spontaneous immortalization of primary BALB/c murine embryo fibroblasts. Genes \& Dev. 5: 23752385.

Haupt, Y., Maya, R., Kazaz, A., and Oren, M. 1997. Mdm2 promotes the rapid degradation of p53. Nature 387: 296-299.

Hirai, H. and Sherr, C.J. 1996. Interaction of D-type cyclins with a novel myb-like transcription factor, DMP1. Mol. Cell. Biol. 16: 6457-6467.

Honda, R., Tanaka, H., and Yasuda, H. 1997. Oncoprotein MDM2 is a ubiquitin ligase E3 for tumor suppressor p53. FEBS Lett. 420: 25-27.

Honda, R. and Yasuda, H. 1999. Association of p19ARF with Mdm2 inhibits ubiquitin ligase activity of MDM2 for tumor suppressor p53. EMBO J. 18: 22-27.

Inoue, K. and Sherr, C.J. 1998. Gene expression and cell cycle arrest mediated by transcription factor DMP1 is antagonized by D-type cyclins through a cyclin-dependent-kinase-independent mechanism. Mol. Cell. Biol. 18: 1590-1600.

Inoue, K., Sherr, C.J., and Shapiro, L.H. 1998. Regulation of the CD13/Aminopeptidase $\mathrm{N}$ gene by DMP1, a transcription factor antagonized by D-type cyclins. J. Biol. Chem. 273: 29188-29194.

Inoue, K., Roussel, M.F., and Sherr, C.J. 1999. Induction of $A R F$ tumor suppressor gene expression and cell cycle arrest by transcription factor DMP1. Proc. Natl. Acad. Sci. 96: 39933998.

Jacobs, J.J.L., Scheijen, B., Voncken, J.-W., Kieboom, K., Berns, A., and van Lohuizen, M. 1999. Bmi-1 collaborates with cMyc in tumorigenesis by inhibiting c-Myc-induced apoptosis via INK4a/ARF. Genes \& Dev. 13: 2678-2690.

Kamijo, T., Zindy, F., Roussel, M.F., Quelle, D.E., Downing, J.R., Ashmun, R.A., Grosveld, G., and Sherr, C.J. 1997. Tumor suppression at the mouse INK4a locus mediated by the alternative reading frame product p19 $\mathrm{ARF}$. Cell 91: 649-659.

Kamijo, T., Weber, J.D., Zambetti, G., Zindy, F., Roussel, M.F., and Sherr, C.J. 1998. Functional and physical interactions of the ARF tumor suppressor with $\mathrm{p} 53$ and Mdm2. Proc. Nat1. Acad. Sci. 95: 8292-8297.

Kamijo, T., Bodner, S., van de Kamp, E., Randle, D.H., and Sherr, C.J. 1999. Tumor Spectrum in ARF-deficient mice. Cancer Res. 59: 2217-2222.

Kastan, M.B., Zhan, Q., El-Deiry, W.S., Carrier, F., Jacks, T., Walsh, W.V., Plunkett, B.S., Vogelstein, B., and Fornace, A.J., Jr. 1992. A mammalian cell cycle checkpoint pathway utilizing p53 and GADD45 is defective in ataxia-telangiectasia. Cell 71: 587-597.

Khan, S.H., Moritsugu, J., and Wahl, G.M. 2000. Differential requirement for $\mathrm{p} 19^{\mathrm{ARF}}$ in the p53-dependent arrest induced by DNA damage, microtubule disruption, and ribonucleotide depletion. Proc. Nat1. Acad. Sci. 97: 3266-3271.

Ko, L.J. and Prives, C. 1996. p53: Puzzle and paradigm. Genes \& Dev. 10: 1054-1072.

Kubbutat, M.H., Jones, S.N., and Vousden, K.H. 1997. Regulation of p53 stability by Mdm2. Nature 387: 299-303.

Land, H., Parada, L.F., and Weinberg, R.A. 1983. Cellular oncogenes and multistep carcinogenesis. Science 222: 771-778. 
Levine, A.J. 1997. p53, the cellular gatekeeper for growth and division. Cell 88: 323-331.

Lloyd, A.C., Obermuller, F., Staddon, S., Barth, C.F., McMahon, M., and Land, H. 1997. Cooperating oncogenes converge to regulate cyclin/cdk complexes. Genes \& Dev. 11: 663-667.

Maestro, R., Dei Tos, A.P., Hamamori, Y., Krasnokutky, S., Sartorelli, V., Kedes, L., Doglioni, C., Beach, D.H., and Hannon, G.J. 1999. Twist is a potential oncogene that inhibits apoptosis. Genes \& Dev. 13: 2207-2217.

Midgley, C.A. and Lane, D.P. 1997. p53 protein stability in tumour cells is not determined by mutation but is dependent on Mdm2 binding. Oncogene 15: 1179-1189.

Miyashita, T. and Reed, J.C. 1995. Tumor suppressor p53 is a direct transcriptional activator of the human bax gene. Cell 80: 293-299.

Momand, J., Zambetti, G.P., Olson, D.C., George, D., and Levine, A.J. 1992. The mdm-2 oncogene product forms a complex with the p53 protein and inhibits p53-mediated transactivation. Cell 69: 1237-1245.

Nevins, J.R. 1998. Toward an understanding of the functional complexity of the E2F and retinoblastoma families. Cell Growth Differ. 9: 585-593.

Oliner, J.D., Pietenpol, J.A., Thiagalingam, S., Gyuris, J., Kinzler, K.W., and Vogelstein, B. 1993. Oncoprotein MDM2 conceals the activation domain of tumour suppressor p53. Nature 362: 857-860.

Palmero, I., Pantoja, C., and Serrano, M. 1998. p19 ${ }^{\text {ARF }}$ links the tumour suppressor p53 to ras. Nature 395: 125-126.

Pantoja, C. and Serrano, M. 1999. Murine fibroblasts lacking p21 undergo senescence and are resistant to transformation by oncogenic Ras. Oncogene 18: 4974-4982.

Pattengale, P.K. and Firth, C.H. 1986. Contributions of recent research to the classification of spontaneous lymphoid neoplasms in mice. Crit. Rev. Toxicol. 16: 185-212.

Pomerantz, J., Schreiber-Agus, N., Liégeois, N.J., Silverman, A., Alland, L., Chin, L., Potes, J., Chen, K., Orlow, I., Lee, H.-W. et al. 1998. The Ink4a tumor suppressor gene product, p19 ${ }^{\mathrm{ARF}}$, interacts with MDM2 and neutralizes MDM2's inhibition of p53. Cell 92: 713-723.

Prives, C. 1998. Signaling to p53: Breaking the MDM2-p53 circuit. Cell 95: 5-8.

Quelle, D.E., Zindy, F., Ashmun, R.A., and Sherr, C.J. 1995. Alternative reading frames of the INK4a tumor suppressor gene encode two unrelated proteins capable of inducing cell cycle arrest. Cell 83: 993-1000.

Quintanilla, M., Brown, K., Ramsden, M., and Balmain, A. 1986. Carcinogen-specific mutation and amplification of Ha-ras during mouse skin carcinogenesis. Nature 322: 78-80.

Radfar, A., Unnikrishnan, I., Lee, H.-W., DePinho, R.A., and Rosenberg, N. 1998. p19 ${ }^{\text {Arf }}$ induces p53-dependent apoptosis during Abelson virus-mediated pre-B cell transformation. Proc. Natl. Acad. Sci. 95: 13194-13199.

Robertson, K.D. and Jones, P.A. 1998. The human ARF cell cycle regulatory gene promoter is a $\mathrm{CpG}$ island which can be silenced by DNA methylation and down-regulated by wildtype p53. Mol. Cell. Biol. 18: 6457-6473.

Roth, J., Dobbelstein, M., Freedman, D., Shenk, T., and Levine, A.J. 1998. Nucleo-cytoplasmic shuttling of the hdm2 oncoprotein regulates the levels of the p53 protein via a pathway used by the human immunodeficiency virus rev protein. EMBO J. 17: 554-564.

Roussel, M.F., Dull, T.J., Rettenmier, C.W., Ralph, P., Ullrich, A., and Sherr, C.J. 1987. Transforming potential of the c-fms proto-oncogene (CSF-1 receptor). Nature 325: 549-552.

Ruas, M. and Peters, G. 1998. The p16 $6^{\mathrm{INK} 4 \mathrm{a}} / \mathrm{CDKN2A}$ tumor suppressor and its relatives. Biochim. Biophys. Acta Rev.
Cancer 1378: F115-F177.

Ruley, H.E. 1983. Adenovirus early region 1A enables viral and cellular transforming genes to transform primary cells in culture. Nature 304: 602-606.

Schmitt, C.A., McCurrach, M.E., de Stanchina, E., Wallace-Brodeur, R.R., and Lowe, S.W. 1999. INK4a/ARF mutations accelerate lymphomagenesis and promote chemoresistance by disabling p53. Genes \& Dev. 13: 2670-2677.

Serrano, M., Hannon, G.J., and Beach, D. 1993. A new regulatory motif in cell cycle control causing specific inhibition of cyclin D/CDK4. Nature 366: 704-707.

Serrano, M., Lee, H.-W., Chin, L., Cordon-Cardo, C., Beach, D., and DePinho, R.A. 1996. Role of the INK4a locus in tumor suppression and cell mortality. Cell 85: 27-37.

Serrano, M., Lin, A.W., McCurrach, M.E., Beach, D., and Lowe, S.W. 1997. Oncogenic ras provokes premature cell senescence associated with accumulation of $\mathrm{p} 53$ and $\mathrm{p} 16^{\mathrm{INK} 4 \mathrm{a}}$. Cell 88: 593-602.

Sewing, A., Wiseman, B., Lloyd, A.C., and Land, H. 1997. Highintensity Raf signal causes cell cycle arrest mediated by p21Cip1. Mol. Cell. Biol. 17: 5588-5597.

Sherr, C.J. 1998. Tumor surveillance via the ARF-p53 pathway. Genes \& Dev. 12: 2984-2991.

Slansky, J.E. and Farnham, P.J. 1996. Introduction to the E2F family: Protein structure and gene regulation. Curr. Top. Microbiol. Immunol. 208: 1-30.

Stott, F., Bates, S.A., James, M., McConnell, B.B., Starborg, M., Brookes, S., Palmero, I., Hara, E., Vousden, K.H., and Peters, G. 1998. The alternative product from the human CDKN2A locus, p14 ${ }^{\mathrm{ARF}}$, participates in a regulatory feedback loop with p53 and MDM2. EMBO J. 17: 5001-5014.

Tao, W. and Levine, A.J. 1999. p19 ${ }^{\mathrm{ARF}}$ stabilizes p53 by blocking nucleo-cytoplasmic shuttling of Mdm2. Proc. Nat1. Acad. Sci. 96: 6937-6941.

Todaro, G.J. and Green, H. 1963. Quantitative studies of the growth of mouse embryo cells in culture and their development into established lines. J. Cell Biol. 17: 299-313.

Weber, J.D., Taylor, L.J., Roussel, M.F., Sherr, C.J., and Bar-Sagi, D. 1999. Nucleolar Arf sequesters Mdm2 and activates p53. Nat. Cell Biol. 1: 20-26.

Weinberg, R.A. 1995. The retinoblastoma protein and cell cycle control. Cell 81: 323-330.

Wu, X., Bayle, J.H., Olson, D., and Levine, A.J. 1993. The p53mdm-2 autoregulatory feedback loop. Genes \& Dev. 7: $1126-1132$.

Yewdell, J.W., Gannon, J.V., and Lane, D.P. 1986. Monoclonal antibody analysis of p53 expression in normal and transformed cells. J. Virol. 59: 444-452.

Zhang, Y., Xiong, Y., and Yarbrough, W.G. 1998. ARF promotes MDM2 degradation and stabilizes p53: ARF-INK4a locus deletion impairs both the $\mathrm{Rb}$ and $\mathrm{p} 53$ tumor suppressor pathways. Cell 92: 725-734.

Zhu, J., Woods, D., McMahon, M., and Bishop, J.M. 1998. Senescence of human fibroblasts induced by oncogenic Raf. Genes \& Dev. 12: 2997-3007.

Zindy, F., Quelle, D.E., Roussel, M.F., and Sherr, C.J. 1997. Expression of the $\mathrm{p} 16^{\mathrm{INK} 4 \mathrm{a}}$ tumor suppressor versus other INK4 family members during mouse development and aging. Oncogene 15: 203-211.

Zindy, F., Eischen, C.M., Randle, D., Kamijo, T., Cleveland, J.L., Sherr, C.J., and Roussel, M.F. 1998. Myc signaling via the ARF tumor suppressor regulates p53-dependent apoptosis and immortalization. Genes \& Dev. 12: 2424-2433.

Zindy, F., Van Deursen, J., Grosveld, G., Sherr, C.J., and Roussel, M.F. 1999. Testicular Atrophy in INK4d-deficient Mice. Mol. Cell. Biol. 20: 372-378. 


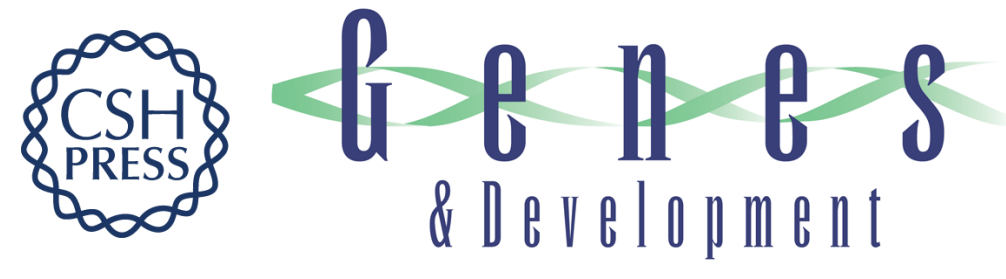

\section{Disruption of the $A R F$ transcriptional activator $D M P 1$ facilitates cell immortalization, Ras transformation, and tumorigenesis}

Kazushi Inoue, Renren Wen, Jerold E. Rehg, et al.

Genes Dev. 2000, 14:

Access the most recent version at doi:10.1101/gad.14.14.1797

References This article cites 68 articles, 31 of which can be accessed free at: http://genesdev.cshlp.org/content/14/14/1797.full.html\#ref-list-1

License

Email Alerting

Receive free email alerts when new articles cite this article - sign up in the box at the top Service right corner of the article or click here.

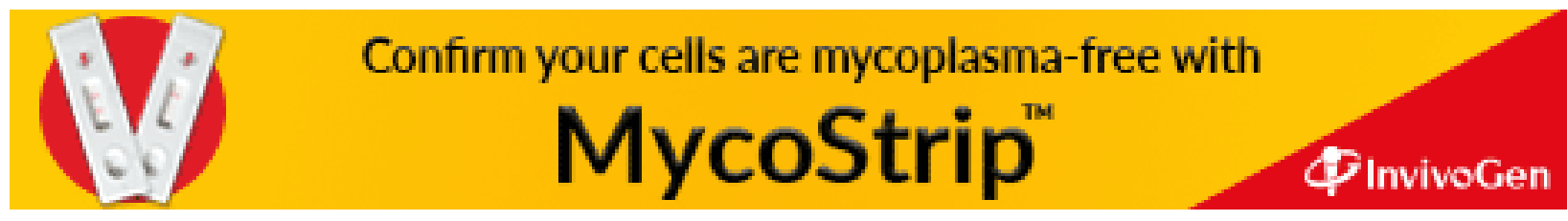

